University of Michigan Law School

University of Michigan Law School Scholarship Repository

\title{
The Execution of Peace with Germany: An Experiment in International Organization
}

\author{
Edwin D. Dickinson \\ University of Michigan Law School
}

Available at: https://repository.law.umich.edu/articles/1169

Follow this and additional works at: https://repository.law.umich.edu/articles

Part of the International Law Commons, Military, War, and Peace Commons, and the Organizations Law Commons

\section{Recommended Citation}

Dickinson, Edwin D. "The Execution of Peace with Germany: An Experiment in International Organization." Mich. L. Rev. 18 (1920): 484-507.

This Article is brought to you for free and open access by the Faculty Scholarship at University of Michigan Law School Scholarship Repository. It has been accepted for inclusion in Articles by an authorized administrator of University of Michigan Law School Scholarship Repository. For more information, please contact mlaw.repository@umich.edu. 


\section{THE EXECUTION OF PEACE WITH GERMANY : AN EXPERIMENT IN INTERNATIONAL ORGANIZATION}

$\mathbf{I}^{\mathrm{N}}$

$\mathrm{N}$ one respect, at least, the Peace of Versailles is unlike any of the great European settlements of earlier date. The provisions included to ensure the execution of its terms are vastly more ambitious in scope and more elaborate in detail than anything of the kind contained in earlier treaties. There is an extraordinary emphasis upon organization for the enforcement of peace.

It may be doubted whether the significance of this emphasis upon organization has been fully appreciated. The notion seems to be widespread that the League of Nations embraces as much of the new organization as is of any real importance and that the primary business of the League is to ensure permanent peace. For the immediate future, certainly, this notion is likely to be very misleading. Two salient facts about the Peace of Versailles are obscured: first, that a temporary organization more powerful than the League has been created to ensure the execution of the settlement; and secondly, that the League itself is more powerfully equipped to enforce the settlement than to ensure permanent peace. It is proposed to show that these are outstanding facts about the settlement by presenting in summary form, with brief comment, the provisions made for ensuring the execution of peace with Germany.

The execution of the Treaty with Germany is entrusted to two types of international organization, each more comprehensive than anything of the kind ever attempted hitherto. The first type is temporary and under the control of the allied great powers. The second is intended to be permanent and is under the control of the League of Nations. Although this régime is likely to be amended somewhat as a result of reservations by the United States and of further developments in Europe, it will be most convenient for the present purpose to present it as it was constituted in the Treaty signed at Versailles. ${ }^{1}$

The temporary organization for executing the settlement ought to be considered first, and perhaps it will be well enough to begin

1 The English text of the Treaty is printed in SEN. Doc. No. 49, 66th Congress, ist session, and also in the Supplement to 13 AMERICAN Journal of INTERNational LAW 128, 151. The French and English texts are printed in SEN. Doc., No. 85, 66th Congress, ist session. 
with the plebiscite commissions. The Treaty with Germany provides for plebiscites in a half-dozen areas within the former Empire." Except in Eupen and Malmédy, where the plebiscite is to be conducted by Belgian authorities, and in the Saar Basin, where the voting will be controlled by the Council of the League, these plebiscites are placed in each instance under the control of an International Commission. Each commission is composed of five members appointed by the five great powers, ${ }^{3}$ except that Japan makes no appointment in Upper Silesia, and the Governments of Norway and of Sweden are each invited to appoint one of the five in Schleswig. The Commission's powers are specified in greatest detail in the clauses dealing with Upper Silesia.

The Commission shall enjoy all the powers exercised by the German or the Prussian Government, except those of legislation or taxation. It shall also be substituted for the government of the province and the Regierungsbezirk.

It shall be within the competence of the Commission to interpret the powers hereby conferred upon it and to determine to what extent it shall exercise them, and to what ex-

₹Art. 34 (in the Kreise of Eupen and Malmédy, ceded to Belgium); Part III, Sec. IV, Annex. Chap. III, pars. 34-35 (in the territory of the Saar Basin, renounced in favor of the League as trustee); Art. 88 and Part III, Sec. VIII, Annex. (in part of Upper Silesia, in favor of Poland); Arts. 94-95 (in part of East Prussia, in favor of Poland); Arts. 96-97 (in part of East Prussia, in favor of Poland); Art. 109 (in upper Schleswig, in favor of Denmark).

3 These powers are the United States, the British Empire, France, Italy, and Japan, described in the Treaty as the "Principal Allied and Associated Powers." Failure to ratify has thus far prevented the representation of the United States on the plebiscite and other commissions.

The resolution of ratification which was defeated in the United States Senate on November 19, 1919, contained, inter alia, the following reservation. "\%. The Congress of the United States will provide by law for the appointment of the representatives of the United States in the assembly and council of the league of nations, and may in its discretion provide for the participation of the United States in any commission, committee, tribunal court, council or conference, or in the selection of any members thereof and for the appointment of members of said commissions, committees, tribunals, courts, councils, or conferences, or any other representatives under the treaty of peace, or in carrying out its provisions and until such participation and appointment have been so provided for and the powers and duties of such representatives have been defined by law, no person shall represent the United States under either said league of nations or the treaty of peace with Germany or be authorized to perform any act for or on behalf of the United States thereunder, and no citizen of the United States shall be selected or appointed as a member of said commissions, committees, tribunals, courts, councils, or conferences except with the approval of the Senate of the United States." See ConGRessional RECORD, 66th Congress, ist session, Vol. 58, p. 9289. The following substitute was approved by the Senate March 4, 1920: " $\%$. No person is or shall be authorized to represent the United States, nor shall any citizen of the United States be eligible, as a member of any body or agency established or authorized by said treaty of peace with Germany, except pursuant to an act of the Congress of the United States providing for his appointment and defining his powers and duties." See ibid., 2d session, Vol. 59, pp. 4147-49. 
tent they shall be left in the hands of the existing authorities. Changes in the existing laws and the existing taxation shall only be brought into force with the consent of the Commission.

The Commission will maintain order with the help of the troops which will be at its disposal, and, to the extent which it may deem necessary, by means of gendarmerie recruited among the inhabitants of the country.

The Commission shall provide immediately for the replacement of the evacuated German officials and, if occasion arises, shall itself order the evacuation of such authorities and proceed to the replacement of such local authorities as may be required.

It shall take all steps which it thinks proper to ensure the freedom, fairness and secrecy of the vote. In particular, it shall have the right to order the expulsion of any person who may in any way have attempted to distort the result of the plebiscite by methods of corruption or intimidation.

The Commission shall have full powers to settle all questions arising from the execution of the present clauses. It shall be assisted by technical advisers chosen by it from among the local population.

The decisions of the Commission shall be taken by a majority vote. ${ }^{4}$ The other Commissions are vested with a somewhat more limited authority, which includes arrangements for local assistance, the decision of questions arising under the plebiscite clauses, control of the voting, and general powers of administration. Decisions in each case are by majority vote. ${ }^{5}$

Cessions of territory stipulated to take effect at once or after a plebiscite require the delimitation anew of several important boundaries. The Treaty defines the new boundaries as accurately as possible and entrusts their actual delimitation to International Boundary Commissions. The Saar Commission is composed of five members, one appointed by France, one by Germany, and three by the Council of the League of Nations, which will select nationals of other powers. ${ }^{\circ}$ The Danzig Commission also consists of five members, one appointed by Germany, one by Poland, and three by

- Part III, Sec. VIII, Annex, part 3.

5 The Treaty with Austria provides for a plebiscite in the Klagenfurt area under the control of a plebiscite commission of similar composition, powers, and procedure.

- Art. $4^{8}$. 
the five great powers. ${ }^{7}$ The remaining Commissions are composed of seven members each, of whom five are nominated by the -five great powers and one by each of the two interested states. ${ }^{8}$ The Saar, Danzig, and Belgian Boundary Commissions have discretion to the extent that they are required to take account respectively of "local economic interests and existing communal boundaries," "existing communal boundaries," and "the economic factors and the means of communication." Otherwise the sole function of each Commission, a function by no means unimportant, is to delimit the particular frontier line on the spot. It is expressly stipulated that the Boundary Commissions, except the one created to trace the Danzig frontier, shall take their decisions by a majority vote and that all decisions shall be binding on the parties concerned. ${ }^{9}$

In a few instances Germany is required to renounce authority over or title to territory in favor of another in the capacity of trustee. Thus the government of the Saar Basin is renounced in favor of the League as trustee, and will be governed for a period of fifteen years at least by a Commission representing the League. ${ }^{10}$ This Commission is composed of five members chosen by the Council of the League, including one citizen of France, one native of the Saar not a citizen of France, and three members belonging to three countries other than France and Germany. ${ }^{11}$

Within the territory of the Saar Basin the Governing Commission shall have all the powers of government hitherto

TArt. xor. The defeat of ratification in the United States has prevented the United States from participating in the appointment of this Commission. See supra, note 3 .

${ }^{3}$ Art. 35 (Belgium-Germany); Art. 83 (Czecho-Slovakia-Poland); Art. 87 (PolandGermany); Art. III (Denmark-Germany). The defeat of ratification in the United States Senate has prevented the United States from participating in the appointment of these Commissions. See supra, note 3.

- The Treaty with Austria provides for the delimitation of new frontiers by boundary commissions of similar composition, powers, and procedure. It may be anticipated that similar commissions will also be established under the treaties with Bulgaria, Hungary, and Turkey. The Treaty with Austria is printed in SEN. Doc. No. 92, 66th Congress, rst session. Texts of the other treaties are not available at the time of writing.

An interesting precedent for the use of boundary commissions is afforded by the intervention of the six great powers of Europe in $188 \mathrm{I}$ to settle the frontier between Turkey and Greece. The Convention of Constantinople of May 24, 188r, between the six powers and Turkey, after defining the new frontier, provided as follows: "This delimitation will be fixed on the spot by a Commission composed of the delegates of the Six Powers and of the two parties interested. The Delimitation Commission will pass their resolutions by a majority of votes, each power having but one vote." Herrscet, MAP of Europe by Treaty, IV, 3042, 3044. The delimitation was fixed by the Commission and the new frontier was handed over, mile by mile, to the Greek authorities. $O p$. cit., IV, 3062-3078.

${ }^{10}$ Art. 49; Part III, Sec. IV, Annex, Chap. II.

11 Part III, Sec. IV, Annex, Chap. II, par. I7. 
belonging to the German Empire, Prussia, or Bavaria, including the appointment and dismissal of officials, and the creation of such administrative and representative bodies as it may deem necessary.

It shall have full powers to administer and operate the railways, canals and the different public services.

Its decisions shall be taken by a majority. ${ }^{12}$ Among the functions specifically enumerated are the levying of taxes, the organization of an appellate court and the settling of its jurisdiction. the decision of all questions with regard to the interpretation of treaty provisions for the territory's government, and the protection abroad of the interests of the inhabitants. ${ }^{13}$ The above régime may be made permanent, provided a plebiscite at the end of fifteen years favors that solution in preference to union with either France of Germany. ${ }^{14}$ Other more transitory arrangements invest the great powers with something of the nature of trusteeship without providing any formal organization. Thus Germany renounces all rights and title over Danzig and a district at the mouth of the Vistula in favor of the great powers, who undertake to establish the town and territory as a Free City under the protection of the League. ${ }^{15}$ A constitution drawn up by representatives of the City in agreement with a High Commissioner appointed by the League will be placed under the League's guaranty. ${ }^{10}$ The great powers further undertake to negotiate a treaty between the Free City and Poland which will make Danzig for most practical purposes a part of the Polish Republic.. ${ }^{17}$ Germany also renounces all rights and title over Memel in favor of the great powers and undertakes to accept whatever settlement they may make with reference to the territory. ${ }^{18}$

The military, naval, and air clauses, for the execution of which the Treaty prescribes a time limit, are to be executed under the con-

12 Ibid., par. 19.

13 Ibid., pars. $26,25,33,21$.

34 Ibid., pars. 34-35.

${ }^{15}$ Arts. 100, 102.

Io Art. I03.

${ }^{17}$ Art. 104. See the Reply of the Allied and Associated Powers to the Observations of the German Delegation on the Conditions of Peace, in INTERnational Coxciliation, No. 144, p. 33.

${ }_{18}$ Art. 99. The great powers also undertake to embody in treaties with CzechoSlovakia and with Poland the provisions necessary for the protection of racial, linguistic, and religious minorities, freedom of transit, and the equitable treatment of foreign com. merce in those states. See Arts. 86, 93, and the Treaty with Poland, printed in Sen. Doc., No. 82, 66th Congress, ist session. A Commission appointed by the great powers and Poland is to prepare a special convention fixing the proportion of the Russian public debt and other public liabilities for which the Polish state is to become responsible. 
trol of Inter-Allied Commissions appointed by the great powers. ${ }^{19}$ There are no provisions with reference to the procedure of these Commissions or the number of members.

The Military Inter-Allied Commission of Control will represent the Governments of the Principal Allied and Associated Powers in dealing with the German Government in all matters concerning the execution of the military clauses.

In particular, it will be its duty to receive from the German Government the notifications relating to the location of the stocks and depots of munitions, the armament of the fortified works, fortresses and forts which Germany is allowed to retain, and the location of the works of factories for the production of arms, munitions and war material and their operations.

It will take delivery of the arms, munitions and war material, will select the points where such delivery is to be effected, and will supervise the works of destruction, demolition, and of rendering things useless, which are to be carried out in accordance with the present Treaty.

The German Government must furnish to the Military Inter-Allied Commission of Control all such information and documents as the latter may deem necessary to ensure the complete execution of the military clauses, and in particular all legislative and administrative documents and regulations. ${ }^{20}$ There are similar articles with reference to the Naval and Aeronautical Commissions. ${ }^{21}$ The Inter-Allied Commissions may establish their organizations at the seat of the Central German Government and may proceed in person or by representatives to any point in German territory. The German Government is required to give all

Treaty with Poland, Art. 2r. The other treaties invest the great powers with similar responsibilities in a variety of circumstances.

Failing ratification, the United States will of course have no part in any of the above transactions. See supra, note 3 .

19 Art. 203. The defeat of ratification in the United States Senate has prevented the United States from participating in the appointment of these Commissions. See supra note 3 .

Similar commissions are provided in the Treaty with Austria, and it may be anticipated that the treaties with Bulgaria, Hungary, and Turkey will contain articles to the same effect.

${ }^{20}$ Art. 208.

${ }^{21}$ Arts. 209, 2ro. The Supplementary Protocol of the same date as the Treaty provides as follows: "A Commission will be appointed by the Principal Allied and Asso. ciated Powers to supervise the destruction of the fortifications of Heligoland in accordance with the Treaty. This Commission will be authorized to decide what portion of the works protecting the coast from sea erosion are to be maintained and what portion must be destroyed." I3 American Journal of International Law, Supplement, 385 . See also the Reply of the Allied and Associated Powers, p. 35. 
necessary facilities for the accomplishment of their missions and must bear all their expenses. ${ }^{22}$

Of all the instrumentalities established primarily to execute the Versailles settlement, the Reparation Commission is indisputably the most important. Its significance can hardly be appreciated without giving some preliminary attention to the program of restitution, restoration, and reparation. This program imposes a stupendous obligation. Germany is compelled to accept responsibility both for itself and its co-belligerents for all loss and damage to the allied governments and their nationals as a result of the war. ${ }^{23}$ It is recognized that German resources will not be adequate to make complete reparation for all such loss and damage; but Germany is required to make restitution wherever possible, to undertake the restoration of Belgium and other invaded areas, and to make reparation for all damage to the allied civilian populations and to their property. ${ }^{24}$ An enumeration of items of damage in respect to which compensation may be claimed from Germany includes all damage to civilians and their surviving dependents from injury or death caused by the acts and operations of war of either group of belligerents, and also all damage to property of the allied states or their nationals, except naval or military works or materials, either caused by acts of the central powers or the direct consequence of any operations of war. The same enumeration includes the cost to allied governments of all war pensions, assistance to prisoners of war and their families and dependents, and allowances to the families and dependents of mobilized persons or persons serving with the forces. ${ }^{25}$

The determination of the exact amount of reparation which Germany must make and the administration of the whole restoration and reparation problem are entrusted to a powerful Reparation Commission. This body is composed of seven delegates, one appointed by each of the great powers, one by the Serb-CroatSlovene state, and one by Belgium. The working membership, however, is always limited to the delegates of five powers. Those appointed by the United States, Great Britain, France, and Italy al-

22 Arts. 205, 206, 207.

23 Art. 23 I.

24 Arts. 232, 238; Part VIII, Sec. I, Annex IV.

2 Part VIII, Sec. r, Annex I. For a full diccussion and vigorous criticism of the reparation program, principally from the economic point of view, see KEYNES, EcoNoMIC Consequences of the Peace, ch. 5. See also the Reply of the Allied and Associated Powers, p. 48 . 
ways participate, and those appointed by the other three powers participate in turn according to the nature of the question before the Commission. ${ }^{26}$ Any other allied or associated power may be represented by a delegate without a vote whenever its interests are under discussion. ${ }^{27}$ The Commission's principal bureau is in Paris, but its meetings are held whenever and wherever convenient. ${ }^{28}$ It may appoint all necessary officers, agents and employees, and may delegate authority and discretion to officers, agents, or committees at pleasure. ${ }^{29}$ Members and authorized agents enjoy diplomatic immunities in Germany. ${ }^{30}$ Each delegate is irresponsible for acts and omissions as a member of the Commission except to the Government appointing him. ${ }^{31}$ All salaries and expenses of the Commission and its staff are paid by Germany. ${ }^{32}$ The organization is to be maintained until the entire obligation imposed upon Germany and its allies has been discharged. ${ }^{33}$ The Treaty apparently anticipates that this period will span the life of at least one generation. ${ }^{34}$

The remarkable thing about the Reparation Commission is the power with which it is invested.

The Commission shall have all the powers conferred upon it, and shall exercise all the functions assigned to it, by the present Treaty.

The Commission shall in general have wide latitude as to its control and handling of the whole reparation problem

${ }^{x}$ Part VIII, Sec. I, Annex II, par. 2. The defeat of ratification in the United States Senate has prevented the representation of the United States on the Reparation Commission. See supra, note 3 .

at Part.VIII, Sec. I, Annex II, par. 3. A somewhat similar practice in dealing with the interests of the lesser states was announced by the European Concert of the great powers in the resolutions adopted at Aix-la-Chapelle in 1818. The paragraph with regard to future meetings of the Concert contained the following provision: "that in the case of these meetings having for their object affairs specially connected with the interests of the other States of Europe, they shall only take place in pursuance of a formal invitation on the part of such of those States as the said affairs may concern, and under the express reservation of their right of direct participation therein, either directly or by their Plenipotentiaries." HertsLet, MAP of EuRofe my Treaty, I, 57r. Bluntsch!i lais it down as a rule that every European state has a right to participate in all the deliberations of the great powers when decisions relating to its own affairs are to be made. VolKerRecht, secs. 105-106. See also Streit, "Les grandes puissances dans le droit international," in Revue de Droit International et DE Legislation CoMparee, (1900) $2^{\circ}$ sér., II, 5, 17. Practice has not been uniform. Compare British and Foreign State Papers, XVIII, 728, and ibid., LXXIV, 1231, 1236, 1238, 124I, 1250 .

28 Part VIrI, Sec. I, Annex II, par. 5.

20 Ibid., par. 7 .

so Art. 240.

31Part VIII, Sec. I, Annex II, par. 2 I.

32 Art. 240.

${ }^{33}$ Part VIII, Sec. I, Annex II, par. 23.

3 Art. 233. 
as dealt with in this part of the present Treaty and shall have authority to interpret its provisions. Subject to the provisions of the present Treaty, the Commission is constituted by the several Allied and Associated Governments, [including those represented and those having an interest in reparation] $* * *$ as the exclusive agency of the said Governments respectively for receiving, selling, holding, and distributing the reparation payments to be made by Germany under this part of the present Treaty. ${ }^{35}$

The greater number of its functions, of course, are ministerial in nature. Thus it is the Reparation Commission's business to receive all money, goods, or valuable rights which are to be paid over or transferred by Germany or for Germany's credit as a part of the reparation program. ${ }^{36}$ In a few cases its approval is required for estimates. ${ }^{37}$ It assesses the value of various kinds of property for credit on the reparation account, ${ }^{38}$ makes calculations of one sort

${ }_{35}$ Part VIII, Sec. I, Annex II, par. 12. "The vast extent and manifold character of the damage caused to the Allied and Associated Powers in consequence of the war has created a reparation problem of extraordinary magnitude and complexity, only to be solved by a continuing body, limited in personnel and invested with broad powers to deal with the problem in relation to the general economic situation. The Allied and Associated Powers, recognizing this situation, themselves delegate power and authority to a Reparation Commission." Reply of the Allied and Associated Powers, p. 49.

See a pamphlet printed for the Senate Committee on Foreign Relations, C C Data on Gerasan Peace Treaty (Washington, 1919), p. 36, for a convenient but incomplete digest of the Commission's powers. See also KEYNEs, op cit, pp. 208-219.

The Reparation Commission is also to administer the reparation problem as regards Austria, and analogous provisions mutatis mutandis are included in the Austrian Treaty. Mrr. Keynes says that there are analogous articles in the Bulgarian Treaty. Op. cit., pp. 2I0, 214. It is not unlikely that the Commission will be invested with similar authority, to be administered by a special section of delegated powers or by a separate but subordinate agency, as regards Hungary and Turkey.

$\approx$ Part VIII, Sec. I, Annex II, par. I2 (in general); Art. 232 (the bonds required to secure repayment of loans by Allied and Associated Governments to Belgium); Part VIII, Sec. I, Annex III, pars. 2, 4 (the merchant ships and fishing boats to be delivered by Germany); ibid., par. 5 (part of the German river fleet); Art. 247 (certain works of art to be restored to Belgium); Art. 256 (payments from the cessionary states on account of German public property situated in the ceded territory); Art. 260 (the rights of Germany and of German nationals in public utilities and concessions abroad).

3i Art. 124 (France's estimate of damages to French nationals in the Cameroons or frontier zone by German authorities or individuals, 1900-14); Art. 125 (France's estimate of amount of deposits, credits, advances, etc., effected in Germany's favor by virtue of conventions and agreements of 1911 and 1912 relative to Equatorial Africa).

${ }^{38}$ Part III, Sec. IV, Annex, Chap. I, par. 5 (value of Saar mines and accessories ceded to France); Art. I45 (value of German owned shares in State Bank of Morocco); Fart VIII, Sec. I, Annex II, par. 19 (value of property accepted in payment of reparation obligations); ibid., Annex IV, par. 5 (value of materials and animals provided for restoration of invaded areas); Art. 250 (value of non-military materials handed over under armistice agreements); Art. 256 (value of public and royal property in ceded territory); Art. 260 (value of German rights in public utilities and concessions abroad). 
and another according to principles defined in the Treaty, ${ }^{39}$ and prescribes the details of a great variety of transactions. ${ }^{40}$ In its most important functions, however, the Reparation Commission is by no means restrained to ministerial administration. The determination of the total reparation bill which Germany will be required to pay may be described more appropriately as a judicial function. The Commission considers the claims, gives the German Government a fair hearing, and concludes its findings and notifies Germany of the extent of its obligations on or before May I, I921. ${ }^{41}$ The power to hear and decide claims in regard to the physical restoration of the invaded areas is of a similar nature. ${ }^{42}$ Other important powers are administrative in the sense in which that term is understood in Europe and in which it has more recently come to be understood in this country. They involve wide discretion in matters of the great-

${ }^{30}$ Art. 254 (the portion of the German public debt of August I, I914, which cessionary states assume on account of the territory ceded); Arts. 92, 255 (the portion of the German public debt which is attributable to public measures for the German colonization of Polish territory); Art. 255 (the portion of the German public debt representing public expenditures on government properties).

${ }^{10}$ Part III, Sec. IV. Annex. Chap. III, par. 36 (terms upon which Germany may create a prior charge upon its assets or revenues to pay France for Saar mines in as much of the Saar Basin as may be restored to Germany after the plebiscite); Art. 232 (amount and form of bonds issued by Germany to reimburse sums borrowed by Belgium from Allied and Associated Governments); Art. 235 (installments and medium of Germany's initial reparation payment); Art. 238 (restitution procedure); Part VIII, Sec. I, Annex II, par. I2 (all details of bond issues by Germany); ibid., par. 15 (form of reparation certificates to be issued to creditor states); ibid., par. 19 (substitution of other medium for payments stipulated in gold or its equivalent); ibid., Annex III, par. 4 (measures for ensuring delivery of ships in specie); ibid., par. 5 (procedure for restitution of river shipping and appliances); ibid., par. 7 (measures for obtaining full title to transferred ships); Art. 247 (details of restoration of Library of Louvain); Art. 254 (method by which cessionary states shall discharge assumed share of German public debt); Art. 296 (currency and rate of exchange in which debts shall be paid where new states are concerned).

The authority to prescribe details, although superficially of a ministerial nature, may casily involve powers of the most far-reaching significance. That the point may be illustrated by Art. 235, cited above, is suggested by the comment of Mr. Keynes. He says: "The Reparation Commission is empowered up to May I, 1921, to demand payment up to $\$ 5,000,000,000$ in such manner as they may fix, 'whether in gold, commodities, ships, securities or otherwise.' This provision has the effect of entrusting to the Reparation Commission for the period in question dictatorial powers over all German property of every description whatever. They can, under this Article, point to any specific business, enterprise, or property, whether within or outside of Germany, and demand its surrender; and their authority would appear to extend not only to property existing at the date of the peace, but also to any which may be created or acquired at any time in the course of the next eighteen months. * * The clause is unequivocal and all-embracing. - Thus the powers of the Reparation Commission * * can be employed to destroy Germany's commercial and economic organization as well as to exact payment." $O p$. cit., p. 78 .

12 Art. 233. Although entitled to a fair hearing, Germany may not take any part whatever in the decisions of the Commission. Part VIII, Sec. I, Annex II, par. ro.

12 Part VIII, Sec. I, Annex IV, pars. 2-4. 
est moment. In the assessment of Germany's liability for reparation, for example, the Commission may require whatever information it wishes with regard to Germany's military operations, its financial situation, and its stocks, current production, and productive capacity of raw materials and manufactured articles. ${ }^{43}$ The Commission has wide authority over everything relative to the securing and discharg. ing of Germany's reparation debt, including power to settle all matters of detail, change the interest rate, and require additional bond issues whenever it thinks them warranted by conditions. ${ }^{44}$ It decides what tonnage of merchant shipping, not to exceed 200,000 tons gross, Germany must lay down each year for a five-year period in discharging the reparation obligation.

The specifications of the ships to be built, the conditions under which they are to be built and delivered, the price per ton at which they are to be accounted for by the Reparation Commission, and all other questions relating to the accounting, ordering, building and delivery of the ships, shall be determined by the Commission. ${ }^{45}$

The Commission may order coal deliveries to I nxembourg, and may control the exercise of options stipulated in favor of states entitled to deliveries of coal and other products. ${ }^{46}$ It may order the delivery by way of reparation of dyestuffs and chemical drugs up to fifty per cent of the total stock in Germany or under German control when the Treaty goes into effect and up to twenty-five per cent of the normal production for five years thereafter. ${ }^{47}$ Within one year from the coming into force of the Treaty, the Commission may direct the acquisition by Germany of all interests owned by German nationals in public utilities or concessions in Russia, China, Turkey, Austria, Hungary, Bulgaria, the possessions of these states, or in any territory formerly belonging to Germany or its allies, and may require the transfer of such interests, together with similar interests held by the German Government itself, to the Commission for credit on the reparation account. ${ }^{48}$

\footnotetext{
15Art. 240. The Supplementary Protocol of the same date as the Treaty provides as follows: "The Reparation Commission referred to in Article 240 and paragraphs 2, 3 and 4 of Annex IV cannot require trade secrets or other confidential information to be divulged." I3 AMERican Journal of INTERNationaI LAw, SUPPLEMENT, 386.

${ }^{14}$ Arts. 233, 234, 243; Part VIII, Sec. I, Annex II, pars. 12, 16; Art. 248. See supra, note 40 .

45 Part VIII, Sec. I, Annex III, par. 5.

so Part VIII, Sec. I, Annex V.

17 Ibid., Annex VI.

${ }^{48}$ Art. 260 .
} 
Finally, and to make assurance doubly sure, Germany is required to recognize the Reparation Commission and to agree "irrevocably to the possession and exercise by such Commission of the power and authority given to it under the present Treaty."49 In case of default by Germany, the Commission notifies the interested powers and recommends whatever action it considers necessary. ${ }^{50}$ In case Germany refuses to perform any of its reparation obligations, the Commission is in a position to invoke the full force of the guarantee which the Treaty provides, namely, the military occupation of German territory west of the Rhine for a period of fifteen years or as much longer as may be considered necessary..$^{\text {st }}$ Article 430 provides as follows:

In case either during the occupation or after the expiration of the fifteen years referred to above the Reparation Commission finds that Germany refuses to observe the whole or part of her obligations under the present Treaty with regard to reparation, the whole or part of the areas specified in Article 429 will be re-occupied immediately by the Allied and Associated forces.

In view of its constitution and its extraordinary powers, the provisions with reference to the Reparation Commission's procedure are of more than ordinary significance. The Treaty provides as follows:

The Commission shall not be bound by any particular code or rules of law or by any particular rule of evidence or of procedure, but shall be guided by justice, equity and good faith. Its decisions must follow the same principles and rules in all cases where they are applicable. It will establish rules relating to methods of proof of claims. It may act on any trustworthy modes of computation. ${ }^{52}$

49 Art. 240. The German delegation protested vigorously against the powers accorded the Reparation Commission. The following is from the German letter transmitting observations on the draft Treaty of Peace: "Even in internal affairs we are to give up the right to self-determination. The International Reparation Commission receives dictatorial powers over the whole life of our people in economic and cultural matters. Its authority extends far beyond that which the Empire, the German Federal Council, and the Reichstag combined ever possessed within the territory of the Empire. This commission has unlimited control over the economic life of the state, of communities, and of individuals." i3 Aserican Journat of International Law 542. See also Keynes, op. cit., pp. 215-219; and compare the reply of the Allied and Associated Powers, p. 50. to Part VIII, Sec. I, Annex II, pars. I7-18. See aiso Art. 430.

ar Arts. 428, 429. See the agreement between the United States, Belgium, the British Empire, France, and Germany, with reference to the military occupation of the Rhine, in SEN. Doc., No. 75, 66th Congress, 1st séssion.

B2 Part VIII, Sec. I, Annex II, par. II. 
Decisions are taken by vote, each delegate being entitled to one vote and abstention counting as a vote in the negative.

On the following questions unanimity is necessary:

(a) Questions involving the sovereignty of any of the Allied and Associated Powers, or the cancellation of the whole or any part of the debt or obligations of Germany;

(b) Questions of determining the amount and conditions of bonds or other obligations to be issued by the German Government and of fixing the time and manner for selling, negotiating or distributing such bonds;

(c) Any postponement, total or partial, beyond the end of I930, of the payment of installments falling due between May I, r92I, and the end of I926, inclusive;

(d) Any postponement, total or partial, of any installment falling due after 1926 for a period exceeding three years ;

(e) Questions of applying in any particular case a method of measuring damages different from that which has been previously applied in a similar case;

(f) Questions of the interpretation of the provisions of this part of the present Treaty.

All other questions shall be decided by the vote of a majority. ${ }^{\text {b3 }}$

Decisions go into effect automatically without further ratification or approval.

Decisions of the Commission, in accordance with the powers conferred upon it, shall forthwith become binding and may be put into immediate execution without further proceedings. ${ }^{54}$

All proceedings of the Reparation Commission are private, unless made public for special reasons on particular occasions. ${ }^{55}$

Other agencies created to ensure the execution of peace terms with Germany, although less important, are at least worthy of mention. If all or part of the Saar Basin is restored to Germany, as a result of the plebiscite to be held fifteen years hence, France's rights in the mines situated in the territory restored are to be repurchased by Germany at a price to be fixed by an International Commission of three experts, one named by Germany, one by France, and one

\footnotetext{
5 Ibid., par. 13.

34 Ibid., par. 14 .

ss Ibid., par. 8.
} 
by the Council of the League. The decisions of this Commission will be made by majority vote. ${ }^{56}$ The repatriation of German prisoners of war and interned civilians is in charge of a Commission composed of representatives of the allied and associated powers and of Germany. ${ }^{5 \tau}$ Commissions in charge of the identification and care of war graves are also contemplated. ${ }^{58}$ Unless the conditions of transfer of an equitable portion of social and state insurance reserves on account of territorial cessions have been arranged within three months after the Treaty becomes effective, they will be determined in each instance by a Commission of five members, one appointed by Germany, one by the other interested state, and three by the Governing Body of the International Labour Office from the nationals of other states. Each Commission will adopt recommendations by a majority vote and submit them to the Council of the League, whose decision will be final. ${ }^{59}$ Another Commission, composed of one German delegate, one Czecho-Slovak delegate, and one British delegate, will delimit in Hamburg and Stettin the free zones which are to be leased to Czecho-Slovakia and will decide the amount of rental and the terms of equipment, exploitation, and utilization. These terms may be revised every ten years in the same manner, Germany agreeing in advance to adhere to the Commission's decisions. ${ }^{60}$ Export Commissions will also be constituted to apportion railway rolling stock for the ceded territories. ${ }^{61}$ A system of national clearing offices for the settlement of debts is made cptional for each allied and associated power. ${ }^{22}$ For the decision of many of the questions which may arise under the clauses dealing with debts, property rights and interests, contracts, prescriptions, judgments, and industrial property, Mixed Arbitral Tribunals are to be established between Germany and each of the allied and associated powers. Each Tribunal is to consist of three members, one appointed by Germany, one by the allied or associated power, and $a$ third by agreement, or, failing an agreement, by the Council of the League. Where the number of cases justifies it, additional members may be appointed and the Tribunal may sit in divisions. The Tribunals determine their own procedure and their decisions

sort III, Sec. IV, Annex, Chap. III, par. 36.

${ }^{51}$ Art. 215. There is an analogous article in the Treaty with Austria.

6s Art. 225. There is an analogous article in the Treaty with Austria.

${ }^{10}$ Art. 312. There is an analogus article in the Treaty with Austria.

$\infty$ Art. 364.

6r Art. 37x. There is an analogous article in the Treaty with Austria.

2 Art. 296 and Annex. There are analogous articles in the Treaty with Austria.. 
are reached by majority vote. ${ }^{63}$ The special tribunal before which it is proposed to try the former German Emperor "for a supreme offense against international morality and the sanctity of treaties" is to be composed of five judges appointed by the five great powers. ${ }^{04}$

The performance of Germany's obligations under the Treaty is guaranteed by the military occupation of the Rhine territory for at least fifteen years. ${ }^{\text {c5 }}$ The Interallied Rhineland Commission, for which provision is made in an Agreement between the United States. Belgium, the British Empire, France, and Germany, is to be the supreme representative of the allied and associated powers within the occupied territory. ${ }^{60}$ This Commission is composed of four members representing the four allied and associated powers. The members enjoy diplomatic privileges and immunities. The Commission is invested with authority to issue ordinances having the force of law, both for the occupying military authorities and the German civil authorities, "so far as may be necessary for securing the maintenance, safety, and requirements of the allied and associated forces," and also to declare a state of siege in all or part of the occupied territory whenever it is deemed necessary. ${ }^{67}$

Viewed as an experiment in international organization, the temporary régime for executing the settlement with Germany has three outstanding features. In the first place, although the Treaty was signed by twenty-seven states, representation on the different commissions is limited to a few states and the controlling representation is in all cases given directly or indirectly to the five great powers. ${ }^{68}$ In the second place, these commissions are invested in varying degree with real powers of control. So far from being mere diplomatic bodies, whose decisions are made ad referendum, they are real governing institutions within the more or less limited scope of their authority. In the third place, most of the commissions and the Mixed Tribunals reach their decisions by majority

est. 304 and Annex. There are analogous articles in the Treaty with Austria.

"Art. 227. See Baldwin. "The Proposed Trial of the Former Kaiser," (1919) 29 YAIE L. Jour. 75. At the date of writing Holland has denied a request for the former Emperor's extradition and it seems unlikely that the proposed trial will ever be held.

${ }^{o 5}$ Arts. 428-432.

Agreement, Art. 2. See supra, note $5 \mathrm{I}$.

- Agreement, Arts. 3, 5, 13 .

cs "This covenant of the league of nations is an alliance and not a league, as is amply shown by the provisions of the treaty with Germany which vests all essential power in five great nations. Those same nations, the principal allied and associated powers, also dominate the league through the council." Majority report from the Committee on Foreign Relations of the United States Senate, SEN. Rep., No. 176, 66th Congress, ist session, p. 7 . 
vote. $^{\text {99 }}$ The most important exception is the requirement of unanimity for the decision of six enumerated kinds of questions by the Reparation Commission. Elsewhere the need for effective action has resulted in a sweeping modification of the time-honored unanimity rule. In brief, traditional notions in regard to the sovereignty, independence, and equality of states have been compromised wherever the representatives of a few great powers have agreed in wanting effective action for the attainment of a fairly well defined end.

Thus far attention has been directed primarily to the temporary organization. The Treaty also provides for a League of $\mathrm{Na}$ tions with a permanent organization, and entrusts a great many important functions in connection with the execution of its terms to certain of the League institutions. ${ }^{70}$ An adequate appreciation of this part of the execution program requires some preliminary attention to the organization of the League.

The League's original membership is planned to include twentyseven states, four self-governing dominions, and India, all signatories of the Treaty with Germany, and as many of the enumerated non-signatory states as accede without reservation. The former belligerents, Austria, Bulgaria, Germany, Hungary, the Russian states, and Turkey, and the former neutrals, Abyssinia, Costa Rica, the Dominican Republic, and Mexico, are included in neither group. ${ }^{71}$ The League's principal instrumentalities are an Assembly, a Council, and a permanent Secretariat. The Assembly is a large body consisting of representatives of all the members. ${ }^{72}$ The Council, on the other hand, is a small body made up at the outset of representatives of the five great powers and of four other powers selected by the Assembly. ${ }^{73}$ The Secretariat includes a Secretary General, appointed by the Council with the approval of a majority of the Assembly, and the necessary secretaries and staff. ${ }^{74}$ There

$\omega$ In addition Art. 437 provides that "in the absence of a subsequent agreement to the contrary, the chairman of any Commission established by the present Treaty shall in the event of an equality of votes be entitled to a second vote."

${ }^{70}$ The Covenant of the League is also incorporated in the Treaty with Austria and niany important functions in connection with the execution of that Treaty are entrusted to League institutions. It may be anticipated that similar use of League institutions will be made in the treaties with Bulgaria, Hungary, and Turkey.

71 Art. I; Part I, Annex.

${ }^{72}$ Art. 3. The defeat of ratification in the United States Senate has prevented the representation of the United States on any of the League institutions organized to date. See supra, note 3 .

ts Art. 4. Until the appointment of representatives by the four other powers first selected by the Assembly, Belgium, Brazil, Greece, and Spain are to be represented on the Council.

is Art. 6. 
is also a permanent Labour Organization consisting of a General Conference and an International Labour Office controlled by a Governing body. ${ }^{75}$ Each member sends four delegates to the General Conference, two representing the Government, one the employers, and one the workers. ${ }^{76}$ The Governing Body in control of the Labour Office is composed of twenty-four persons, of whom twelve are selected to represent Governments, six are elected by delegates to the General Conference representing employers, and six by delegates representing workers. Of the twelve selected to represent Governments, eight are nominated by the members which are of the chief industrial importance and four by members selected for the purpose by the Government delegates of the other states at the Conference. Any question as to which are the member states of chief industrial importance is to be decided by the Council of the League. ${ }^{77}$ The Labour Office is in charge of a Director appointed by the Governing Body; the Director appoints his staff. ${ }^{78}$ The League will have no judicial institutions at the outset, but plans for a Permanent Court of International Justice are to be formulated by the Council and submitted to the members for adoption. ${ }^{79}$ Of administrative institutions, in addition to those already mentioned, there will be a great variety. One permanent commission will be created to advise the Council in regard to the limitation of armaments and another to receive and examine the reports of mandatories and to advise the Council on matters relating to the observance of mandates. ${ }^{80}$ The European Commission of the Danube and the Rhine Central Commission are continued with important changes of representation, and provision is made for several new international commissions to take charge of the administration of other rivers. $^{82}$ All the rivers commissions include representatives of nonriparian states. ${ }^{82}$ The proposed Convention relating to Interna-

${ }^{73}$ Art. 388.

7 Art. 389.

77 Art. 393.

7. Arts. 394, 395 .

72 Art. 14.

${ }^{0}$ Arts. 9, 22.

Arts. $340,34 \mathrm{r}, 342,346,347,354,355$.

* This feature is made the object of vigorous criticism by Mr. Keynes, in op. cit., p. zro. The author says: "The objectionable feature of the Commissions lies in their membership. In each case the voting is so weighted as to place Germany in a clear minority. On the Elbe Commission Germany has four votes out of ten; on the Oder Commission three out of nine; on the Rhine Commission four out of nineteen; on the Danube Commission, which is not yet definitely constituted, she will be apparently in a small minority. On the government of all these rivers France and Great Britain are represented; and on the Elbe for some undiscoverable reason there are also representatives of Italy and Belgium. Thus the great waterways of Germany are handed over 
tional Air Navigation ${ }^{\$ 3}$ provides for an International Commission for Air Navigation composed of one representative of Great Britain and one of each of the British Dominions and of India, two representatives of each of the other four great powers, and one representative of each of the other contracting states. ${ }^{84}$ Existing international bureaus, so far as the consent of the parties to the general treaties by which they are established can be obtained, and all international bureaus and commissions established in the future are to be placed under the direction of the League. ${ }^{85}$

The covenants of the League of Nations are more important than its organization. In Article Io the member states "undertake to respect and preserve as against external aggression the territorial integrity and existing political independence of all members of the League." In Article I2 they "agree that if there should arise between them any dispute likely to lead to a rupture, they will submit the matter either to arbitration or to inquiry by the Council, and they agree in no case to resort to war until three months after the award by the arbitrators or the report by the Council." Measures for fulfilling the obligation imposed by Article ro are to be recommended by the Council in each case. More detailed provision is made for the execution of Article 12. The controversies to be settled by arbitration are defined as those which the members "recognize to be suitable for submission to arbitration and which cannot be satisfactorily settled by diplomacy." This definition is expressly made to include controversies in regard to the interpretation of treaties, questions of international law, questions of material fact, and questions involving the extent and nature of reparation. The parties to the dispute may either agree upon a court of arbitration or it may be stipulated in any conven-

to foreign bodies with the widest powers; and much of the local and domestic business of Hamburg, Magdeburg, Dresden, Stettin, Frankfurt, Breslau, and Ulm will be subject to a forcign jurisdiction. It is almost as though the Powers of Continental Europe were to be placed in a majority on the Thames Conservancy or the Port of London."

The reasons for non-riparian representation are set forth in the reply of the allies to the observations of the German delegation on the conditions of peace. "Delegates from non-riparian states are included in the River Commissions as well as representatives of the riparian states, in the first place as representing the general interest in free circulation on the rivers regarded as transit routes; and, secondly, so that within the River Commission themselves they may act as a check on the strongest riparian state abusing her preponderating influence to the detriment of the others. For the same reason, in deciding upon the number of representatives allotted to each riparian state, the great factor of freedom of communication must rank first." Reply of the Allied and Associated Powers, p. 85.

*Sen. Doc., No. 9r, 66:h Congress, ist session. See also Lee, "The International

Flying Convention and the Freedom of the Air" (1919) 33 HARv. L. REv. 23.

84. 35.

8 Art. 24. 
tion existing between them. It is agreed that arbitral awards will be carried out in good faith and that no state will resort to war against a member which complies with the award. If a member fails to comply, the Council will propose measures for making the award effective. ${ }^{86}$ All serious controversies which are not submitted to arbitration must be submitted to an inquiry by the Council. Either party may accomplish this by giving notice to the Secretary General, whereupon the parties must communicate statements of their case with all relevant facts and papers to the Secretary General and the Council will attempt to settle the dispute. Failing a settlement the Council will publish a report of the case with recommendations. ${ }^{e r}$ If this report is approved by all members of the Council, other than representatives of parties to the controversy, it is agreed that no member shall go to war with the member which complies with the recommendations. Otherwise complete liberty of action is reserved. The Council may refer any dispute to the Assembly, and is obliged to do so if either party requests it within fourteen days after submission. ${ }^{88}$

Sanctions are provided to ensure the observance of the covenants. Resort to war in disregard of the covenants is to be regarded as ipso facto an act of war against all other members; and the members undertake to sever trade and financial relations, prohibit all intercourse between their nationals and nationals of the covenantbreaking state, and prevent all financial, commercial, or personal intercourse between nationals of the covenant-breaking state and the nationals of any other state, whether a member of the League or not. The use of joint forces to protect the covenants of the League is also contemplated, although not expressly made obligatory, and free passage is promised for such forces. The members agree to a fair apportionment of the burdens incident to all coercive measures. Covenant-breaking states may be expelled from the League by a unanimous vote of the Council; disregarding, of course, any vote cast by a representative of the expelled state. ${ }^{89}$ Moreover,

\footnotetext{
$\approx$ Art. 13.

87 If the dispute is claimed by one party and is found by the Council to arise out of a matter which by international law is solely within the domestic jurisdiction of that party, the Council will report accordingly and will make no recommendations. Art. 15.

${ }_{28}$ In attempting to settle disputes thus referred, the Assembly will be controlled by the same provisions which apply to the Council, except that its report and recommendations, failing a settlement, will become effective if concurred in by the delegates of all members represented on the Council and by a majority of the delegates of other members, exclusive in each case of delegates representing parties to the dispute. Art. 15 .

$\$$ Art. 16 . See address of President Wilson on presenting the draft of the Covenant to the third plenary session, February 14, 1918, in (1919) I3 Americas Jouris or INTERAATIONAL LAW 570,573 .
} 
the above sanctions may be applied to states which are not members of the League. In the event of a dispute between a member and a non-member, or between non-members, the parties may be invited to accept the obligations of membership for the purpose of such dispute upon conditions prescribed by the Council. If a state refuses the invitation and resorts to war against a member, all the sanctions outlined above are to be invoked against the aggressor. If both parties to a dispute refuse such an invitation, the Council may take such measures and make such recommendations as will prevent hostilities and bring about a settlement of the controversy. ${ }^{90}$

The permanent organization of the League has a two-fold function to perform: its ultimate function is to promote international coöperation and preserve peace; its immediate function is to ensure the execution of the Versailles settlement. It is this latter purpose which seems to have received somewhat less emphasis than it deserves. In so far as League institutions are equipped to ensure permanent peace, their most important powers, with a few exceptions, are of an advisory or ministerial character. The Assembly has almost no power at all. In presenting the draft of the Covenant to the third plenary session, President Wilson remarked that the Assembly had been given "unlimited rights of discussion." It may discuss "any matter within the sphere of action of the League or affecting the peace of the world," 92 but it has few powers of any real importance. Probably the most important are the power to admit new members to the League by two-thirds vote, to select the states which are to be represented on the Council with the five great powers, and to settle disputes referred to it by the Council.93 The powers of the Council are defined in the same generous terms and with somewhat greater effect. The Council is the League's most powerful institution. The most important of its functions are advisory; for example, the duty to formulate and submit plans for a permanent court, to formulate plans for the reduction of armaments. to endeavor to settle disputes referred to it for inquiry and, failing a settlement, to make a report with recommendations, to advise as to the means of fulfilling the obligation imposed by Article Io, and to recommend the forces to be contributed by members in order to protect the covenants of the League. ${ }^{94}$ In a few instances it has

\footnotetext{
$\infty$ Art. 17.

21 (1919) 13 American Journal of International Law 570, 572.

D. Art. 3 .

Arts. $1,4,15$.

A Arts. 14, 8, 15, 10, 16.
} 
real power to control. It is authorized, for illustration, to change the seat of the League at any time, to define the authority of mandatories in the absence of previous agreement among League members, to prescribe the conditions and modifications under which the covenant may be applied to disputes in which states outside the League are parties, and to expel a covenant-breaking state from the League. ${ }^{95}$ It may increase its own membership with the approval of the Assembly. ${ }^{96}$ In the event of war or threat of war, it may join the Assembly in taking "any action that may be deemed wise and effectual to safeguard the peace of nations." ${ }^{\text {"9r }}$ The most important functions of the Labour Organization are advisory or ministerial in character. ${ }^{98}$ The river commissions will exercise an extensive administrative control over the navigation of rivers, ${ }^{99}$ and if the proposed Commission for Air Navigation is established it will probably enjoy a somewhat less extensive administrative control over the navigation of the air..$^{100}$

The immediate business of the League is to assist in the execution of the Versailles settlement. It will do this in part through the exercise of the powers with which League institutions have been permanently invested. It is hardly putting it too emphatically to say that unless the League succeeds in preserving peace in Europe and in promoting a measure of international coopperation there will remain no foundation upon which to base the execution of the settlement. To this extent, at least, the League's ultimate function and its immediate function are identical. There are other instances in which no sharp distinction can be drawn between the immediate and the ultimate function of League institutions. The internationalization of German rivers, for example, will be made effective by the river commissions in the exercise of the powers with which they have been permanently invested. In addition to their general powers, certain League institutions have been equipped for the execution of the settlement with important special powers. The League itself becomes trustee for the Saar Basin, undertakes to protect Danzig and guarantee its constitution, and exercises an ill-defined supervision over the mandatories to which former colonies and

\footnotetext{
${ }^{\infty 6}$ Arts. 7, 22, I7, 16.

20 Art. 4 .

$n$ Art. Ix. This clause is of course much less significant than it appears to be because neither the Council nor the Assembly has power to do anything more in such an event than to recommend and advise.

98 Arts. 400 ff.

Atts. 346, 354, 348, 343, 344. See SAyre, Experinents in Internationat. ADMINISTRATION, pp. 38-47, 13I-14I.

${ }^{100}$ Convention selating to International Air Navigation, Art. 35 .
} 
territories of the central powers are to be entrusted. ${ }^{101}$ The Council of the League makes several appointments to positions in the temporary régime, including three members of the Saar Boundary Commission, the Governing Commission of the Saar, one of the three experts on the price of the Saar mines, the High Commissioner of Danzig, and the president of the Mixed Arbitral Tribunal in each instance in which the parties fail to agree on a candidate. ${ }^{102}$ Several important decisions in connection with the execution of the Treaty with Germany are left to the League. The League decides, for example, on the effect to be given the plebiscite in Eupen and Malmédy; it decides on the permanent disposition to be made of the Saar Basin after the plebiscite; it decides disputes in regard to the revival of treaties with Germany; and it must approve any general conventions relating to the international régime of transit, waterways, ports, or railways. ${ }^{103}$ The Council of the League fixes the conditions, methods, and date of voting in the Saar plebiscite; it settles the arrangements in regard to amounts of coal, duration of contracts, and prices in the event that the Saar mines are eventually restored to Germany and France acquires in consequence the stipulated right to purchase coal for industrial and domestic needs; it may assent to the alienation of Austrian independence; it may extent the period of certain of Germany's obligations; it must decide finally the conditions of transfer of social and state insurance reserves unless these conditions are settled by special conventions between the parties; and it may order any investigation of Germany which it considers necessary. ${ }^{104}$ Finally, the League through one or more of its institutions is entrusted with the execution of several important transactions relating to the settlement. After the plebiscite in the Saar and the League's decision as to the future of that region, the Council will make all necessary provisions for the estab-

101 Arts. 49, 102, 103, 22.

100 Arts. 48, 49; Part III, Sec. IV, Annex, Chap. II, pars. 16, 17, I8; ibid., Chap. III par. 36; Arts. 103, I04.

103 Art. 34; Part III, Sec. IV, Annex, Chap. III, par. 35; Arts. 289, 338, 379.

104 Part III, Sec. IV, Annex, Chap. III, par. 34; ibid., par. 37; Arts. 80, 280, 378, 312, 213. The treaties between the United States and France and between Great Britain and France for assistance to France in the event of unprovoled aggression by Germany must be approved by the Council, acting if need be by a majority, as engagements consistent with the Covenant of the League. They are to continue in force until on the application of one of the parties the Council, acting if need be by a majority, decides that the League itself affords sufficient protection. Art. 3, in SEN. Doc., No. 63, 66th Congress, Ist session, pp. 7,13 .

The Council also exercises a kind of supervision over the protection of racial, seligious, and linguistic minorities in Poland, and may assent by a majority vote to the modification of the relevant articles of the Polish Treaty. Treaty with Poland, Art. 12. There are similar stipulations in the Treaty with Austria. 
lishment of the permanent régime. ${ }^{105}$ If Germany and Poland fail to agree, the terms of conventions between them relative to railroad, telegraphic, and telephonic facilities will be settled by the Council. ${ }^{106}$ After Germany has been admitted to the League, the armament establishment fixed in the Treaty may be modified by the Council $^{103}$ The League will provide a river commission for the Niemen on request from any riparian state. ${ }^{108}$ Many of the articles relating to commerce and transport may be revised by the Council at any time after five years from the coming into force of the Treaty. ${ }^{109}$

In view of the important part which the League is to take in the execution of peace with Germany, it will be profitable to compare it in certain particulars with the temporary organization for executing the settlement. It has been pointed out, in the first place, that representation on the temporary institutions is limited to a few states and for most practical purposes to the five great powers. It is noteworthy that the Ieague institution selected to take the largest part in the execution of the settlement is the Council, a small body dominated by representatives of the five great powers. In the second place, the temporary institutions are invested in varying degree with real powers of control. It is noteworthy, again, that while the Council of the League is equipped principally with advisory powers in order to promote international coopperation and preserve peace, it is invested with some real powers of control in order to ensure the execution of the settlement. In the third place, it has been noted that in the temporary organization the principle of majority decisions is extensively substituted for the unanimity requirement. It is of some significance that, matters of procedure excepted, the only instances in which the Council can take its decisions by majority vote are concerned with the execution of the settlement. In all matters pertaining to the Saar Basin, in extending the period during which Article 276 in regard to the treatment of nationals of the allied and associated powers is to remain in force, and in ordering any investigation in regard to Germany the Council arrives at its decisions by a majority vote. ${ }^{110}$ In the League, as in the tem-

\footnotetext{
${ }^{105}$ Part III, Sec. TV, Annex, Chap. III, par. 39.

${ }^{108}$ Art. 98

100 Art. 164 .

109 Art. 342.

100 Art. 378.

${ }^{110}$ Part III, Sec. IV, Annex, Chap. III, par. 40; Arts. 280, 213. The Council also acts by a majority vote in assenting to the modification of stipulations in the Polish Treaty for the protection of minorities, in approving the treaties for assistance to France, and in deciding that the treaties for assistance to France may be safely terminated. See
} 
porary régime, it is an outstanding feature that where effective action is an agreed desideratum the difficulties in the way of adequate organization are not insuperable. ${ }^{111}$

Without in any way disparaging the significance of the League of Nations as an instrument for preserving peace, it is suggested that for the immmediate future at least the régime established to ensure the execution of the settlement is of greater importance. No more significant experiment in international organization has ever been adventured. The experiment indicates that some degree of real international government is feasible, and that in so far as real international government is achieved traditional theories requiring equality of representation, decisions ad referendum, and unanimity will be rendered obsolete. If the experiment is even partially successful it may point the way for improving the League organization as an instrument for preserving peace. It may indicate, indeed, that when the statesmen of responsible powers become as anxious about international coöperation and peace as they are about the execution of terms with Germany the essential measures will be quite within the reach of practical statecraft.

University of Michigan Law School.

Eidwin D. Dickinson.

supra, note ro4. It will decide several important questions in connection with the execution of the Austrian Treaty by majority, and it may be anticipated that the same principle will be adopted in provisions for the execution of the other treaties.

III The point is illustrated also by the International River Commissions and by the proposed Commission on Air Navigation. 